\title{
Distribution, status and conservation of the bats of the Fiji Islands
}

\author{
Jorge M. Palmeirim, Alan Champion, Alifereti Naikatini, Jone Niukula, Marika Tuiwawa, Martin Fisher, \\ Mere Yabaki-Gounder, Sólveig Thorsteinsdóttir, Stanley Qalovaki and Thomas Dunn
}

\begin{abstract}
The poorly studied bat fauna of the Fiji Islands is of notable conservation importance because it includes one endemic species, several near endemics, and the best global populations of several threatened species. In addition, some of the species play a keystone role as pollinators and seed dispersers in valuable forest ecosystems. We visited 30 islands of the archipelago to survey bats and assess their conservation status and the potential threats to their continued existence. The Vulnerable Notopteris macdonaldi occurs on the three main islands but may only have nurseries on one of them. The Critically Endangered, endemic Mirimiri acrodonta appears to be restricted to a small montane area on a single island. Pteropus tonganus is consumed throughout rural Fiji but remains common and is not currently threatened by the harvest. The Near Threatened Pteropus samoensis is locally common on the largest islands but threatened on some smaller islands. The Endangered
\end{abstract}

Chaerephon bregullae exists only on two islands and appears to concentrate in a single large colony to nurse young. The Endangered Emballonura semicaudata has declined dramatically in Fiji, as across most of its range, although a few substantial populations remain on some small islands. Factors threatening these species are variable but include small ranges, concentration in a reduced number of colonies, deforestation, over-harvesting, and introduced predators. We propose conservation measures and indicate a number of priority sites.

Keywords Bats, Fiji, Notopteris macdonaldi, Mirimiri acrodonta, Pteropus samoensis, Pteropus tonganus, Emballonura semicaudata, Chaerephon bregullae.

This paper contains supplementary material that can be found online at http://journals.cambridge.org

\section{Introduction}

Bats are the only mammals native to most of the Pacific archipelagos and geographic isolation has resulted in the evolution of several endemic species. Of particular

Jorge M. Palmeirim (Corresponding author) and Sólveig Thorsteinsdóttir Departamento de Biologia Animal e Centro de Biologia Ambiental, Faculdade de Ciências, Universidade de Lisboa, 1749-016 Lisboa, Portugal. E-mail palmeirim@fc.ul.pt

Alan Champion*, Martin Fishert, Mere Yabaki-Gounder and Thomas Dunn Department of Biology, School of Pure and Applied Sciences, University of the South Pacific, Suva, Fiji.

Alifereti Naikatini and Marika Tuiwawa South Pacific Regional Herbarium, Institute of Applied Science, University of the South Pacific, Suva, Fiji.

Jone Niukula Fiji National Trust, 3 Ma'afu Street, Suva, Fiji.

Stanley Qalovaki Department of Fisheries, Ministry of Forest and Fishery, Suva, Fiji.

${ }^{*}$ Current address: School of Medicine, University of Tasmania, Private Bag 99, Hobart, Tasmania 7001, Australia.

${ }^{\dagger}$ Current address: Fauna \& Flora International, Jupiter House, Station Road, Cambridge, CB1 2JD, United Kingdom.

Received 18 April 2006. Revision requested 27 October 2006.

Accepted 29 March 2007. importance, fruit bats appear to be keystone species in Pacific island ecosystems, where they are essential pollinators and seed dispersers (Cox et al., 1991; Elmqvist et al., 1992; Rainey et al., 1995). This critical role became particularly important after the disappearance of potential dispersers and pollinators as a result of the extinction of bird species that followed the expansion of humans across the Pacific (Steadman \& Martin, 2003). Flying foxes are presently the only likely aerial dispersers of a number of plant species with large seeds (Rainey et al., 1995; McConkey \& Drake, 2002).

The first human colonizers of Pacific islands also had a negative impact on bats. They may have caused the extirpation of three of the five species of bats in the archipelago of Tonga (Koopman \& Steadman, 1995), and in the last century there was a general decline in the populations of several bat species in the Pacific, with extirpations taking place in many islands and archipelagos (Rainey, 1998) and several species and subspecies becoming highly threatened (Mickleburgh et al., 1992; Rainey, 1998; Hutson et al., 2001). As a result of their particular vulnerability, insular bats now form a large proportion of the World's threatened bats (Mickleburgh et al., 2002). 
With $>300$ islands and a total land surface of $18,272 \mathrm{~km}^{2}$ Fijian territory is a substantial proportion of the total landmass of Pacific archipelagos. The Fiji archipelago is ecologically diverse, including small volcanic or limestone islands and large volcanic islands with considerable climatic variation. Consequently, Fiji is a key country for the conservation of Pacific plant and animal species. Four of Fiji's six bat species are either endemic or near endemic, with four Megachiroptera (Notopteris macdonaldi, Mirimiri acrodonta, Pteropus samoensis and Pteropus tonganus), and two insectivorous Microchiroptera (Emballonura semicaudata and Chaerephon bregullae). An old record of a species of Nyctophilus is doubtful (Parnaby, 2002a).

In spite of its importance the bat fauna of Fiji has received little scientific or conservation attention. The only extensive contribution to the knowledge of the Fijian bat fauna comes from collecting trips carried out in 1990 and 1991 (Ingleby \& Flannery, 1991; Flannery, 1995). However, with bats declining throughout the Pacific it is vital to know their status in Fiji to be able to plan appropriate conservation measures. The research reported here aimed to (1) examine the distribution and status of bats in Fiji, (2) identify key sites for their protection, (3) identify potential threats to species and key sites, and (4) suggest appropriate conservation measures.

\section{Methods}

The south-east, windward sides of the larger Fijian islands receive considerable orographic precipitation, and in spite of ongoing logging there are still relatively large areas of native forest. The leeward sides are drier, now have little forest, and are dominated by reed grasslands, crops and pasture. Smaller islands tend to be drier and, although a few are well forested, most have little remaining native forest. Along the shores of most islands there are extensive coconut groves and vegetable and fruit gardens. Some of the reed grasslands that now cover substantial parts of several islands may have a natural origin but they have also spread by human action (Nunn, 1997).

Field surveys included all the larger islands and samples of most groups of smaller islands (Fig. 1). Between September 2000 and February 2001 we visited

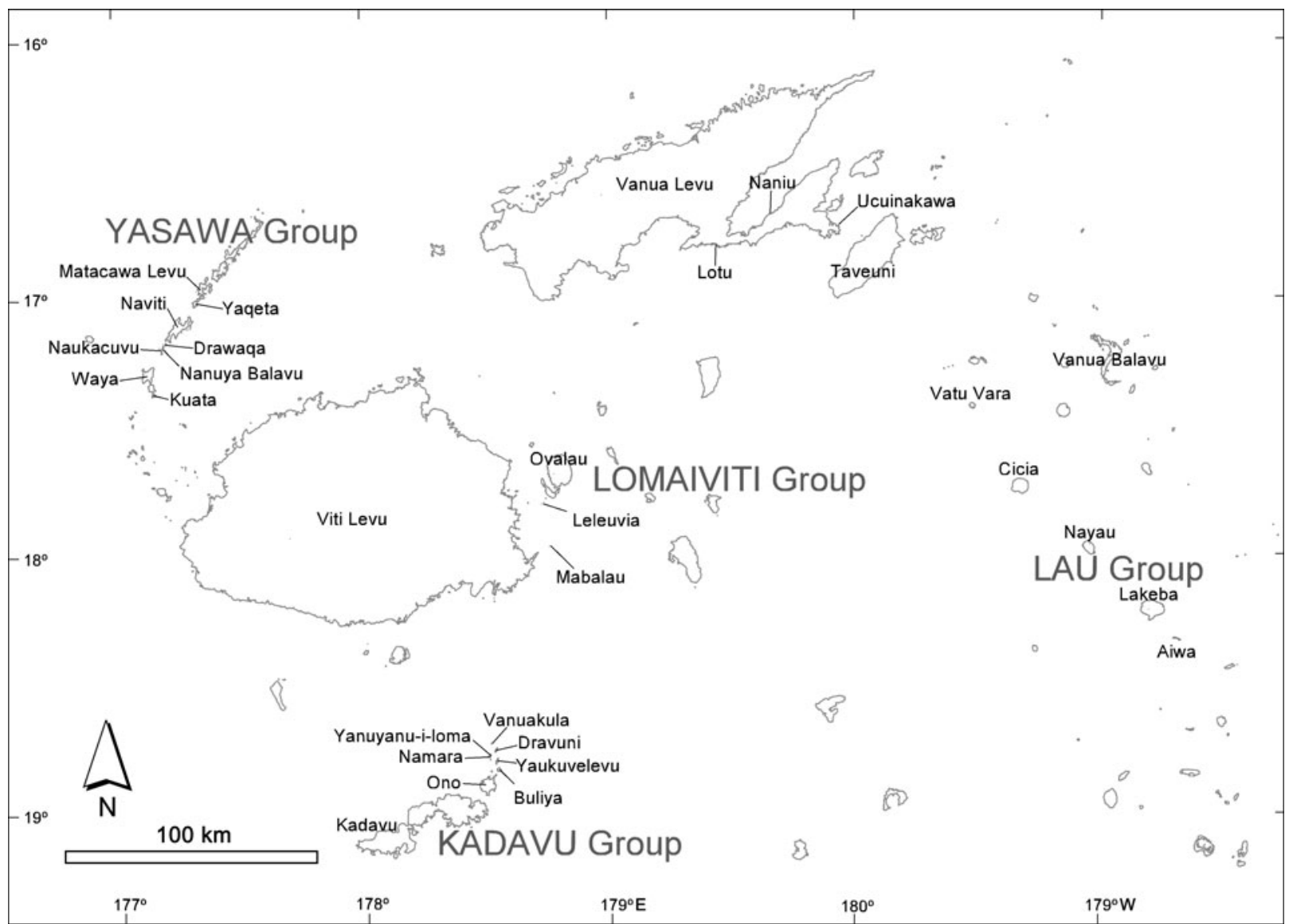

Fig. 1 Fijian islands surveyed for bats. 
a total of 30 islands, including the larger islands of Viti Levu, Vanua Levu, Taveuni, and islands in the Yasawa, Kadavu, Lomaiviti and Lau groups. The small Rotuma island group, located c. $400 \mathrm{~km}$ to the north of Viti Levu, was not surveyed.

The survey work carried out by the Australian Museum in 1990 - 1991 (Ingleby \& Flannery, 1991; Flannery, 1995) included some visits to caves but most observations were obtained by mist netting, especially in the forested interior of the largest islands. Because a considerable amount of the type of data that it is possible to collect with this methodology was therefore already available, we prioritized the search for cave dwelling species and their roosts, although also attempted to collect information about non cave-dwelling species.

The majority of Fijian land is traditionally owned, and access requires prior permission from the community hierarchy, usually obtainable after a traditional ceremony. These protocols were always followed, and the ensuing conversation with village leaders was an opportunity to gather valuable information. During these meetings, and in the frequent evening conversations around the traditional kava drinking bowl, we asked questions to (1) locate potential roosts, (2) identify perceived population trends, (3) detect factors potentially affecting bat populations, (4) identify any conflicts between bats and farming activities, and (5) detect the presence of $P$. samoensis. To cross-check any information received we asked the same questions of independent groups of people. Generally older people had better knowledge of their village lands and fauna but, because their information could refer to a relatively distant past, we also tried to obtain information from younger villagers. During most of these various village meetings we had opportunity to talk about the objectives of our project, the ecological relevance of bats, and the conservation problems they face.

We visited almost all the caves in which anyone consulted had observed bats. In some cases mist nets were placed across the entrance of unoccupied caves to capture transient bats. We attempted to explore all the sections of accessible caves. When bats were present we made approximate visual evaluations of their numbers, although this was often difficult for a variety of reasons: N. macdonaldi roosts in caves with very high ceilings, E. semicaudata disperses at the first signs of light, and C. bregullae roosts in large crevices inside caves. In addition, white-rumped swiftlets Aerodramus spodiopygius were often present in the same cave chambers, sometimes flying around in large numbers. A bat detector was used to detect E. semicaudata flying among swiftlets.

We also set up mist nets at several locations and attempted to visit most of the P. tonganus camps that we were informed of. Bats present at these camps were counted directly or their numbers were estimated from a viewpoint. In many areas we also walked transects using a bat detector to locate foraging E. semicaudata and C. bregullae.

To evaluate the conservation status of the species at country-level we used the IUCN Red List categories and criteria (IUCN 2001, 2003 \& 2006).

\section{Results}

A summary of our findings for each species is provided in Table 1. The locations where we made observations are illustrated in Figs. 2-3, and key sites for the protection of Fiji's bats in Fig. 4. Details of all sites that we searched for bats or where we received information regarding their presence or absence are provided in the Appendix. Our country-level Red List assessments (Table 1) are similar to the global assessments (IUCN, 2006) with the exception that we categorize P. tonganus as Near Threatened rather than Vulnerable, and C. bregullae as Endangered rather than Lower Risk: near threatened.

Notopteris macdonaldi We found four nursing colonies of this species, all of them in caves on Viti Levu. At the times of our visits three of the colonies were very large. We were unable to locate roosts on Vanua Levu or Taveuni. These are both volcanic islands where limestone is rare, and there are no large karstic caves such as those that harbour colonies on Viti Levu. These four caves therefore probably harbour most of the country's population of this species. Local people confirmed that the four caves have been occupied by bats for many years.

Mirimiri acrodonta We were unable to confirm or dismiss the possible occurrence of this species in the montane forests of Vanua Levu, a possibility raised by German Pavel who observed what was possibly this species near Delaikoro peak (pers. comm.). Until information to the contrary is available, we assume that $M$. acrodonta is restricted to the montane forest of the mid sized island of Taveuni.

Pteropus samoensis This species does not congregate in conspicuous camps and in most areas is much less abundant than $P$. tonganus and therefore more difficult to observe. Consequently, most of the known locations correspond to reports by local people who were familiar with both species. P. samoensis is present throughout much of the larger Fijian islands and in some of the medium sized islands visited but is more dependent on forest than $P$. tonganus. On the larger islands it is therefore more abundant in regions with extensive tracts of native forest, and in the medium sized islands it is associated with patches of forest, although it can forage away from this habitat. We did not identify key 
Table 1 The six species of bat occurring in Fiji, with their endemism, global (IUCN, 2007) and Fijian Red List categories (based on the results of this survey), summary of the main observations of the survey (see Appendix), and earlier observations.

\begin{tabular}{|c|c|c|c|c|c|c|}
\hline Species & $\begin{array}{l}\text { Most common } \\
\text { Fijian name }\end{array}$ & Endemism & $\begin{array}{l}\text { Global Red } \\
\text { List category } \\
\text { (criteria) }\end{array}$ & $\begin{array}{l}\text { Fiji Red } \\
\text { List category } \\
\text { (criteria) }\end{array}$ & $\begin{array}{l}\text { Main } \\
\text { observations }\end{array}$ & $\begin{array}{l}\text { Observations by } \\
\text { Ingleby \& Flannery } \\
(1991), \text { Flannery } \\
\text { (1995) }\end{array}$ \\
\hline \multicolumn{7}{|l|}{ Megachiroptera } \\
\hline $\begin{array}{l}\text { Fijian blossom bat } \\
\text { Notopteris macdonaldi }\end{array}$ & $\begin{array}{l}\text { Manumanu } \\
\text { vaka bui }\end{array}$ & Fiji, Vanuatu & VU (A2d) & $\begin{array}{l}\text { VU (A4acd, } \\
\text { B1ab(iii,v)) }\end{array}$ & $\begin{array}{l}4 \text { nursing colonies on } \\
\text { Viti Levu (200-2,000 } \\
\text { individuals in each); } \\
\text { roosts not found on } \\
\text { Vanua Levu or } \\
\text { Taveuni }\end{array}$ & $\begin{array}{l}\text { Netted on Vanua } \\
\text { Levu \& Taveuni } \\
\text { but could not find } \\
\text { roosts on these } \\
\text { islands }\end{array}$ \\
\hline $\begin{array}{l}\text { Fijian monkey-faced } \\
\text { bat Mirimiri acrodonta }\end{array}$ & & Taveuni (Fiji) & $\mathrm{CR}(\mathrm{A} 1 \mathrm{c}, \mathrm{B} 1+2 \mathrm{c})$ & CR (B1ab(iii)) & Not located & $\begin{array}{l}\text { Netted on Taveuni } \\
\text { but not on Vanua } \\
\text { Levu or Viti Levu }\end{array}$ \\
\hline $\begin{array}{l}\text { Samoan flying-fox } \\
\text { Pteropus samoensis }\end{array}$ & Beka lulu & Fiji, Samoas & $\mathrm{VU}(\mathrm{A} 1 \mathrm{~d}+2 \mathrm{~d})$ & NT & $\begin{array}{l}\text { Present throughout } \\
\text { most of the larger } \\
\text { islands \& on some } \\
\text { of the medium } \\
\text { sized islands }\end{array}$ & $\begin{array}{l}\text { Netted on the three } \\
\text { largest islands }\end{array}$ \\
\hline $\begin{array}{l}\text { Pacific flying-fox } \\
\text { Pteropus tonganus }\end{array}$ & Beka dina & $\begin{array}{l}\text { SW Pacific } \\
\text { isles }\end{array}$ & & & $\begin{array}{l}\text { Present in many } \\
\text { locations on larger } \\
\text { islands, \& common } \\
\text { on medium and } \\
\text { small sized islands. }\end{array}$ & $\begin{array}{l}\text { Observed or netted } \\
\text { on the surveyed } \\
\text { islands }\end{array}$ \\
\hline \multicolumn{7}{|l|}{ Microchiroptera } \\
\hline $\begin{array}{l}\text { Pacific sheath-tailed } \\
\text { bat Emballonura } \\
\text { semicaudata }\end{array}$ & Beka beka & $\begin{array}{l}\text { Polynesia and } \\
\text { Micronesia }\end{array}$ & EN (A1ac) & $\begin{array}{l}\text { EN (A1ace, } \\
\text { B1b(i,ii,iii,iv,v) })\end{array}$ & $\begin{array}{l}\text { Present on many } \\
\text { islands, from islets } \\
\text { to larger islands; } \\
\text { appears to be } \\
\text { extirpated from Viti } \\
\text { Levu but is still } \\
\text { present on Vanua } \\
\text { Levu }\end{array}$ & $\begin{array}{l}\text { Observed on } \\
\text { Ovalau, Taveuni, } \\
\text { and on one island } \\
\text { in the Yasawas }\end{array}$ \\
\hline $\begin{array}{l}\text { Fijian mastiff-bat } \\
\text { Chaerephon bregullae }\end{array}$ & Kalakalavo & Fiji, Vanuatu & $\mathrm{LR} / \mathrm{nt}$ & EN (B1ab(iii)) & $\begin{array}{l}\text { Present only on } \\
\text { Taveuni \& Vanua } \\
\text { Levu, where a large } \\
\text { nursery was located }\end{array}$ & $\begin{array}{l}\text { Recorded on Vanua } \\
\text { Levu and Taveuni }\end{array}$ \\
\hline
\end{tabular}

conservation sites for this species because of its wide range. However, because its best populations live in the well forested areas of the large islands the preservation of native forest is crucial for this species. This partial dependency on wooded habitats suggests that small tracks of forest remaining on medium sized islands, and isolated patches of forest in the dry parts of large islands are important for P. samoensis.

Pteropus tonganus We observed this species commonly on the majority of the small islands visited, and in many locations on the large ones. Islands that do not harbour regular camps may be visited by animals roosting on neighbouring islands. Twenty camps were located in our survey, but this is only a small fraction of the camps in Fiji. From the observations made on the 30 islands visited we can infer that $P$. tonganus uses the majority, if not all, islands of the Fijian archipelago in which it can find food. We observed it feeding on small islets, such as the 13.5 ha Yanuyanu-i-loma, in the Astrolabe archipelago near Kadavu. However, it is absent in the Rotuma archipelago (Clunie, 1985). Due to the abundance of $P$. tonganus we do not indicate key sites for its protection. It is often perceived by village Fijians as a pest but this negative image is countered by its value as a food resource.

Emballonura semicaudata This species has a wide range in the archipelago and is present on large islands to small islets. It may have been extirpated from Viti Levu but is still present on Vanua Levu, Fiji's second largest island. We found one colony inhabiting a small pair of islets (Aiwa in the Lau archipelago) that have a combined surface area of only $1.2 \mathrm{~km}^{2}$. This is the only bat species present on Rotuma (Clunie, 1985). Important sites for the protection of this species are mostly located on small and mid sized islands in the Lau group. We visited caves occupied by E. semicaudata on the islands of 


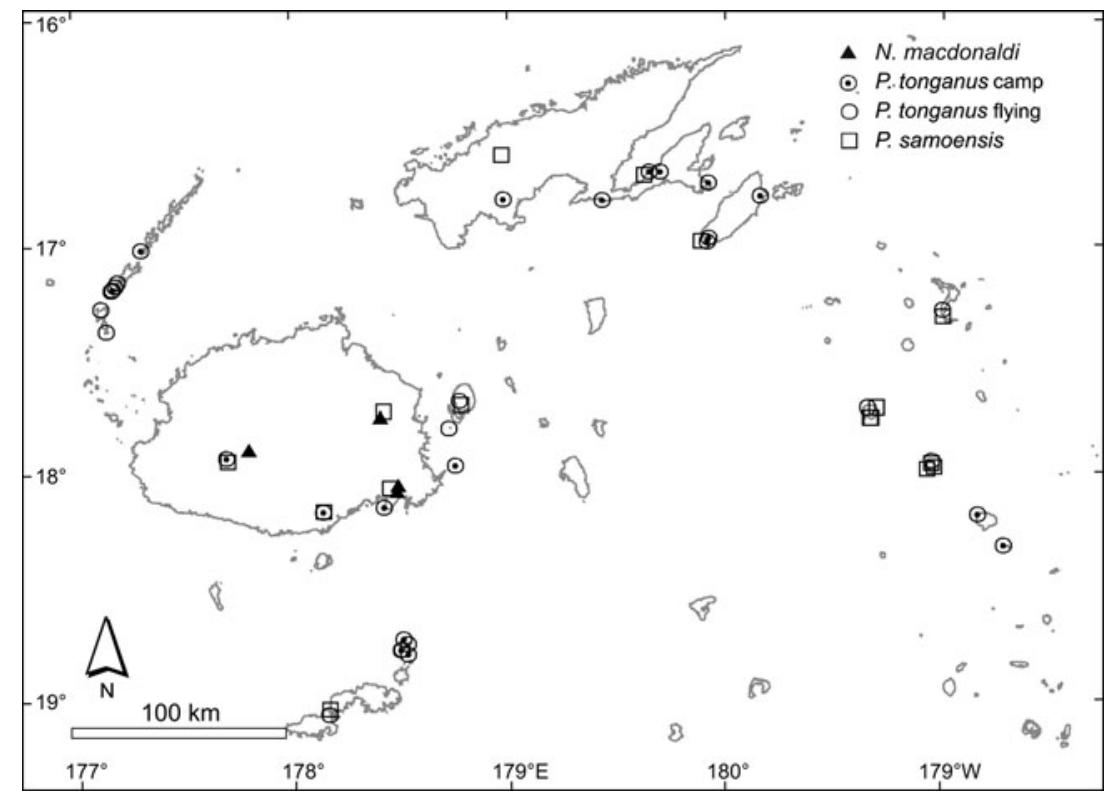

Fig. 2 Observations of Megachiroptera, showing caves harbouring N. macdonaldi, camps and observations of flying individuals of $P$. tonganus (only one observation is marked in each island, but on some we made hundreds), and locations where we found P. samoensis (in many cases these are not direct observations but reports by reliable informants).
Aiwa, Lakeba, Nayau and Cicia, saw pictures of a large colony on Vatu Vara (Adrian Tarte, pers. com.), and received reports of its presence on other Lau islands such as Totoya. The caves and remaining forest patches on them are critical for the long-term conservation of E. semicaudata but any sites with viable populations elsewhere in Fiji are also important. The cave and forest where we found a colony with several hundred individuals on Yaqeta, in the Yasawa archipelago, is of key importance because of the size of the colony.

Chaerephon bregullae We found this species with bat detectors in a few locations on the islands of Vanua Levu and Taveuni. However, we only located one roost, a cave near the village of Nakanacagi, on Vanua Levu. Although C. bregullae emits powerful search calls, easily heard with detectors, we failed to locate the species on the largest island, Viti Levu, or on the many small and medium sized islands surveyed. We cannot exclude its presence elsewhere, especially on some of the larger islands of the Lomaiviti group that we did not survey. The large mudstone cave (Qara ni Beka Beka) at Nakanacagi harbours several thousand individuals and as it is the only known nursery of this species in Fiji it is a key site for its conservation. There may be other nurseries in unknown caves or possibly in other types of roost but maximum care is required for this one known roost site.

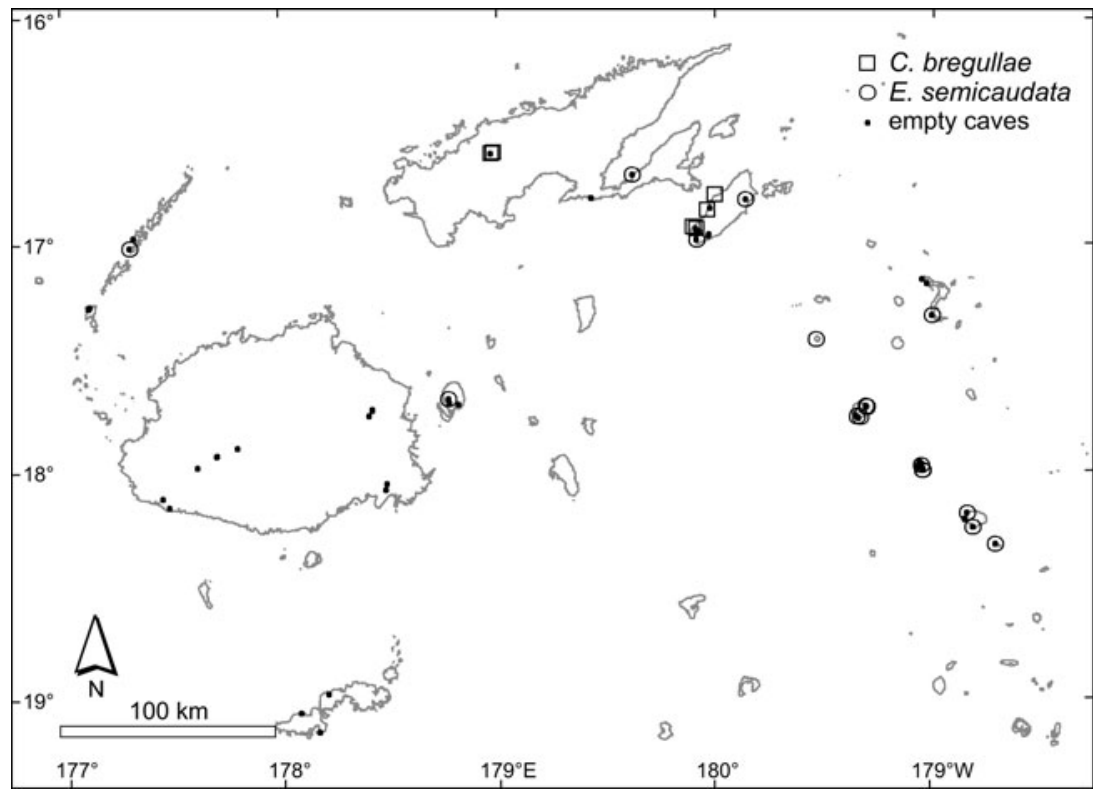

Fig. 3 Observations of Microchiroptera, showing sites where we located foraging C. bregullae, caves in which we observed E. semicaudata, and visited caves where the species was not present (for most of these we had reports of past occupation; see Appendix). Some symbols represent more than one location. 


\section{Discussion}

\section{Potential threats}

It is difficult to objectively assess the relative role of the various factors that could potentially threaten the bats of Fiji and little can be said about some of them (e.g. insecticides and pathogens), although this does not mean they are irrelevant. However, some of the potential threat factors deserve comment because of their presumed impact and relevance to the planning of conservation measures. These comments are based on the results of our observations and on our many discussions with villagers.

Roost disturbance Three of Fiji's bats (N. macdonaldi, C. bregullae and E. semicaudata) roost in caves and are probably sensitive to disturbance of their roosts. In the past some colonies were disturbed by guano mining (pers. comm., villagers), and the cave at Wailotua (Fig. 4) once had a small railway track to carry guano. Such largescale activities were discontinued several decades ago but disturbance is increasing due to the widespread availability of electric torches, which facilitate access, and the desire to find activities for tourists. The latter is particularly relevant for caves harbouring nurseries of
$N$. macdonaldi because they are large and the bats are a significant attraction. Two of the four known nurseries of N. macdonaldi, Wailotua and Tatuba (Fig. 4), are already visited by tourist groups. The other two caves have streams running through the main gallery, making visitation difficult. The current impact of visitation is moderate and could be made compatible with bat conservation.

Roost loss Karstic caves are abundant on a few islands of the Lau group but scarce or localized on most other islands. Among the main islands only Viti Levu has a few isolated pockets of limestone in which there are well developed caves. Vanua Levu, Taveuni, and Kadavu are almost exclusively volcanic, and the only karstic caves on them are very small (Gilbert, 1984). Taveuni, however, has a few potential underground roosts in well developed lava tubes and there is a large mudstone cave on Vanua Levu. On the main islands caves are therefore a limiting resource for bats, particularly for species requiring spacious cavities. Two of the four Fijian caves harbouring nurseries of N. macdonaldi are only $3 \mathrm{~km}$ apart. Availability of underground roosts may also be limiting for C. bregullae and E. semicaudata, although less so for the latter because it can form nurseries in small caves. Because of the rarity of caves,

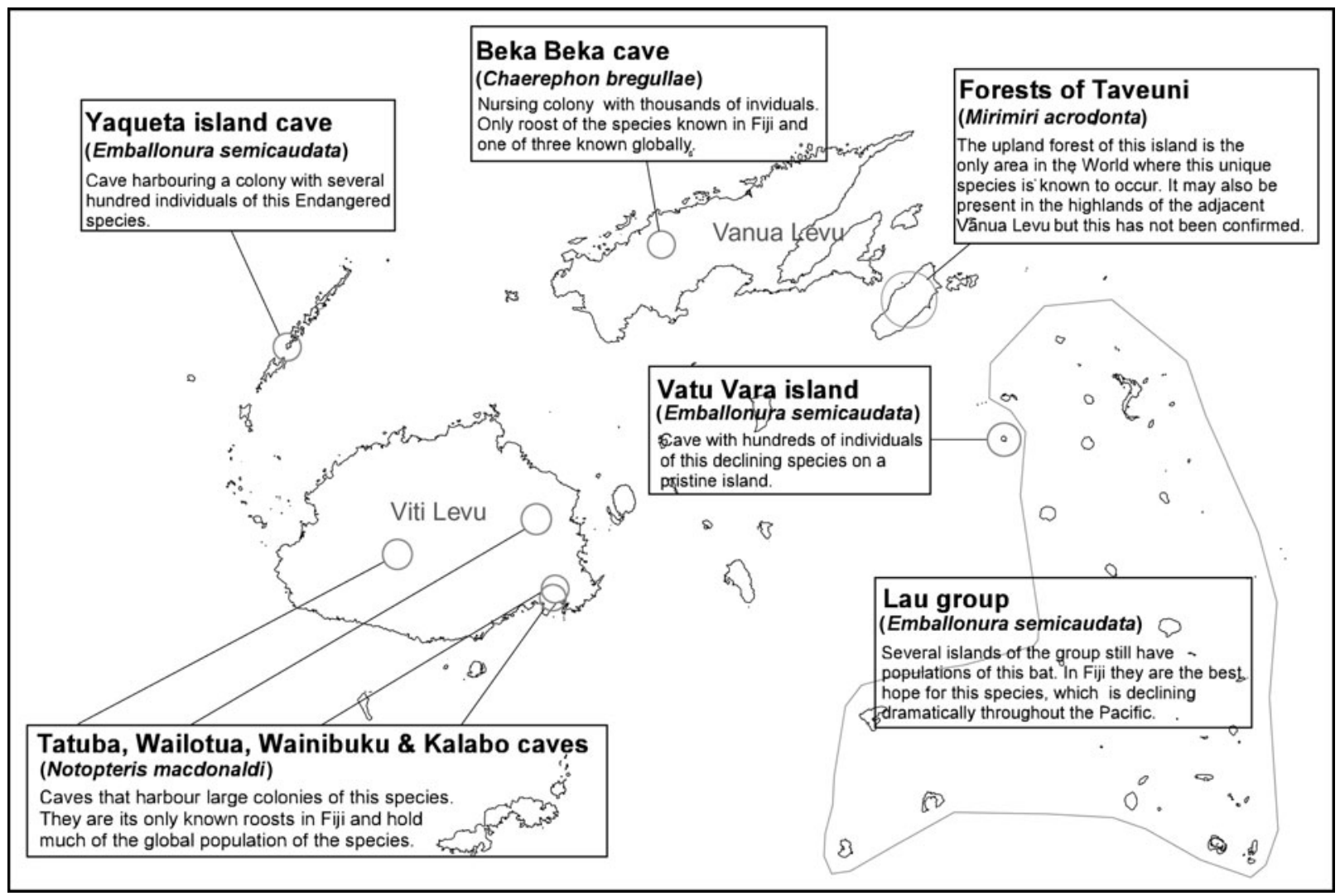

Fig. 4 Key sites for the protection of bats in Fiji (see text for details). 
the high concentration of bats in them, and the often marked faithfulness of cave dwelling bats to their natal roosts, the loss of individual caves can have serious consequences for regional bat populations. We found a cave partly destroyed by road works near Savusavu on Vanua Levu and received information that it once harboured bats, presumably E. semicaudata, although they may have disappeared before the damage to the roost. We found several caves, including some inhabited by E. semicaudata, with entrances totally or partly blocked by dense vegetation. This is caused by the removal of the trees with large canopies that usually shade cave entrances; the increased light reaching the undergrowth promotes its expansion over the entrances.

Harvesting Over-harvesting, especially on a commercial basis, has caused the recent extirpation of flying foxes on a number of islands in the Pacific (Rainey, 1998). P. tonganus and P. samoensis are among the species that have been affected by over-harvesting in the region (Craig et al., 1994; Brooke \& Tschapka, 2002). However, Fiji was not an important exporter of bats in the past, and international trade in P. tonganus and P. samoensis is now prohibited by CITES. Internal commercial harvest of flying foxes does not seem to be important in Fiji; only once did we meet someone who sporadically killed bats for sale. The most frequently consumed species is $P$. tonganus but we did not find any evidence that its populations are significantly affected by the current level of harvest. Harvesting also does not seem to threaten $P$. samoensis on the main islands but it may affect less numerous populations on smaller islands. Hunting pressure on both Pteropus species does not seem to be increasing but needs to be monitored. $N$. macdonaldi and C. bregullae are also harvested but this is problematic because their populations are concentrated in only a few caves where they are easily killed in large numbers. Such over-harvesting was the most likely cause of the extirpation of these two species from Tonga after the arrival of Polynesian colonizers (Rainey, 1998).

Introduced predators Several terrestrial predators, notably feral cats and the mongoose Herpestes javanicus, have been introduced to Fiji (Pernetta \& Watling, 1978; Morley, 2004). The tree dwelling Pteropus spp. do not seem to be affected except in the aftermath of hurricanes; we were told that at these times dogs and cats take large numbers of weakened individuals, a behaviour also reported in Samoa (Craig et al., 1994; Pierson et al., 1996). Feral cats wait for bats as they emerge from caves and catch them in flight (Tuttle, 1977; Ransome, 1990), and they can be responsible for a high proportion of the mortality of some species (Racey \& Entwistle, 2003). Terrestrial predators may be able to take E. semicaudata directly from its roosts, which are often in exposed sites such as shallow caves, rock overhangs or cave entrances. On Cicia (Lau) we observed a cat next to the entrance of a cave that contains a colony of E. semicaudata, far from any settlement. On Lakeba (Lau), a cave that once harboured a large colony is now empty and called Qara ni Pusi (cave of the cat). E. semicaudata probably suffers less predation on islands where it uses roosts with large entrances or that are inaccessible to cats, such as the roosts on offshore islets in Palau (Wiles, 1997). Feral cats are widespread in Fiji, and were the single most important factor responsible for the decline of iguanas and other herpetofauna in the archipelago (Gibbons, 1984; Harlow et al., 2007), and of other vertebrates throughout the Pacific (Atkinson \& Atkinson, 2000; Courchamp et al., 2003).

Hurricanes Strong storms, such as those that caused dramatic declines of $P$. tonganus and $P$. samoensis in the Samoas (Craig et al., 1994, Pierson et al., 1996) and Tonga (McConkey et al., 2004), also occur in Fiji. In Samoa mortality was caused by shortages of food because trees were stripped of flowers and fruits, and we received reports of similar post-storm starvation in Fiji. P. samoensis in the Samoas was much less affected by storms in native forest reserves than in other parts of the islands (Pierson et al., 1996). Hurricanes can cause heavy mortality in E. semicaudata and may have caused the virtual extirpation of populations on Samoa (Tarburton, 2002) and American Samoa (Grant et al., 1994). Shallow caves may not provide protection against strong winds, and some coastal roosts are inundated by rough seas (Grant et al., 1994). Storms may temporarily lower insect abundance (Tarburton, 2002) and prevent bats from foraging for several consecutive days (Grant et al., 1994). Although E. semicaudata has endured hurricanes for millennia, deforestation may be worsening the impact of storms. Under the protection of canopies of well developed forests, such as those where we observed E. semicaudata foraging on Yaqeta, bats are able to forage even during relatively strong winds. If forest is available E. semicaudata can survive even on very small islands (e.g. Yaqeta and Aiwa), in which hurricanes tend to have a greater impact on vertebrates (McNab, 2002).

Deforestation Although the large Fijian islands still have some areas of native forest, much of it has been lost and commercial logging continues. This affects all Fiji's bat species but especially E. semicaudata, N. macdonaldi and $P$. samoensis, which are particularly dependent on forest habitat. The loss of forest on small islands may be particularly harmful for $P$. samoensis. Our observations and those of others (Pierson et al., 1996; Banack, 1998; Brooke, 2001) suggest that while it can forage in various habitats it is more dependent on forest than P. tonganus. Our observations in Fiji and a study in the Mariana Islands (Esselstyn et al., 2004) suggest that forest is the preferred foraging habitat of E. semicaudata. 


\section{Status and global relevance of the Fijian bat fauna}

Notopteris macdonaldi Although this species has a broad range it is only known to breed on Viti Levu. Unlike most Megachiroptera it roosts in caves (Medway \& Marshall, 1975; Nelson \& Hamilton-Smith, 1982). The four known caves with nurseries have large entrances that open into spacious galleries or chambers with high ceilings. These characteristics may be important for this bat, which cannot fly in completely dark cavities (Nelson \& Hamilton-Smith, 1982). Such caves are uncommon, especially on Vanua Levu and Taveuni. It is possible that $N$. macdonaldi also uses smaller caves or hollow trees; its congener Notopteris neocaledonica has been found in one very small cave (Sanborn \& Nicholson, 1950). But although such sites may be suitable transient roosts, they are unlikely to fulfil the requirements of nursing colonies. Distances between the three islands where the species has been found are well within the range of fruit bat migrations (Fleming \& Eby, 2003), and therefore the presence of $N$. macdonaldi on an island is not proof that there are nurseries there. The concentration of this species in a few large nursing colonies makes it vulnerable to stochastic events and overharvesting. There have been rapid declines in other cave dwelling Megachiroptera (Heaney \& Heideman, 1987; Flannery, 1989). N. macdonaldi was extirpated in Tonga following the arrival of Polynesian colonizers (Koopman \& Steadman, 1995) and has declined in Vanuatu, and $N$. neocaledonica has declined in New Caledonia (T. Flannery, in Mickleburgh et al., 1992). Harvesting in some of the nurseries is a substantial source of mortality. Bone remnants of N. macdonaldi found in Fijian caves presently not used by the species may indicate that it was once more widespread (T. Worthy, pers. comm.). The Fijian population of N. macdonaldi probably represents more than half of the global population.

Mirimiri acrodonta This is a recently created genus, monospecific and endemic to Fiji (Helgen, 2005). Known specimens (Hill \& Beckon, 1978; Flannery, 1995) came from an area of montane forest of c. 6,000 ha (Ingleby \& Flannery, 1991) on Taveuni, and the species is not common there (Flannery, 1995). The status of M. acrodonta is similar to that of its closest relatives, the species of the genus Pteralopex, which are restricted to one or a few islands in the Solomon archipelago (Parnaby, 2002b). They are all in a critical situation because their small insular ranges make them highly vulnerable to habitat destruction and stochastic events (Fisher \& Tasker, 1997; Parnaby, 2002b).

Pteropus samoensis In the medium term the status of this species on the larger islands appears to be secure because there are still good areas of forest, and harvesting is not intensive. The species may, however, already have been extirpated on some smaller islands. Our interviews indicated, for example, that until a few decades ago it was present on Lakeba but it is now only found on neighbouring islands with larger extensions of native forest. The Fijian population is an endemic subspecies, P. s. nawaiensis, which represents the majority of the global population of the species. The nominal subspecies is restricted to the Samoas but has declined dramatically (Craig et al., 1994b; Pierson et al., 1996) and, although it has partly recovered, remains threatened (Brooke 2001; Utzurrum et al., 2003). It was extirpated from Tonga following the arrival of Polynesian colonizers (Koopman \& Steadman, 1995).

Pteropus tonganus There is no evidence of a decline of this species in Fiji. Wilson \& Engbring (1992) estimated a population of hundreds of thousands, and our observations concur. We observed individuals making long inter-island flights, and therefore populations on small islands are probably not isolated. The Fijian population of this wide ranging Pacific species is P. tonganus tonganus, which is also present on Wallis and Futuma, Tonga, Cook, and the Samoas (Miller \& Wilson, 1997). From the number of islands in these archipelagos and their surface, we deduce that the Fijian population constitutes considerably more than half of the global population.

Emballonura semicaudata This species has the broadest range of any Pacific bat but it has declined dramatically in Samoa (Tarburton, 2002), American Samoa (Grant et al., 1994) and the Mariana Islands (Lemke, 1986). Fiji has one of the largest extant populations and also harbours most of the global population of the typical subspecies (Koopman, 1997). In Fiji E. semicaudata suffered both a range contraction and a decline in density on some of the islands where it still occurs. It is probably extirpated on the largest island, Viti Levu, where we did not find it in the many caves in which the species was observed up to the 1970s (Watling \& Pernetta, 1978; Gilbert, 1984; M.K. Tarburton, pers. comm.). Some of these used to harbour hundreds (Watling \& Pernetta, 1978) or even thousands (Sawyer \& Andrews, 1901) of individuals. We also failed to discover the species on Kadavu, and found it to be rare on Vanua Levu and Taveuni. The situation is better in Lau but even there the colonies were in general small, many caves were empty, and we heard credible evidence of steep declines. Past observations in Palau (Wiles, 1997) and Rotuma (Clunie, 1985) demonstrate that healthy populations of E. semicaudata can be dense. We conclude that on large and medium islands the extant populations are probably far fewer than formerly but on some small islands the species is faring better. The peculiar range of this species may explain why it is so vulnerable. In spite of a capacity to disperse over water it apparently failed to establish populations on any of the biologically rich islands located 
along the western edge of its range. This failure to thrive in species-rich communities suggests that it cannot cope well with competition or with predation, interactions that presumably increased with the multiple species introduced by humans across its range. Susceptibility to pathogens could be a major cause of the species' decline but we do not know of any confirmed mass mortality of Microchiroptera caused by pathogenic agents.

Chaerephon bregullae If the colony at Nakanacagi is the only nursery in the archipelago, then the species is in a critical situation in Fiji, especially as it is subject to disturbance and harvesting. Its detection at multiple locations on Taveuni and Vanua Levu is not proof that there are other nursing colonies as Molossid bats are powerful fliers that can forage more than $30 \mathrm{~km}$ from day roosts, fly several hundred $\mathrm{km}$ in a single night, and cross large bodies of water (Marques et al., 2004). The Somosomo Strait separating Vanua Levu from Taveuni is only $8 \mathrm{~km}$ wide. Extirpations from Tonga and presumably from Viti Levu, where bones of this species have been found (Worthy \& Anderson, 1999), give further cause for concern.

\section{Conservation}

The conservation of Fiji's native forests is critical for the archipelago's bat species. Remnants of forest on the eastern sides of the larger islands of Viti Levu and Vanua Levu are critical to avoid range contractions of $N$. macdonaldi and P. samoensis. Forest on small and medium islands is of particular importance for E. semicaudata and P. samoensis. Entrances of caves need to be kept free of vegetation and the trees that shade the entrances need to be protected and, in some cases, trees that have been removed need to be replaced. The control or elimination of introduced predators, especially cats, is important on small islands with E. semicaudata. Wherever this is not feasible or locally acceptable, predation could be reduced by building cat proof fences around roosts (Long \& Robley, 2004). Cat control must be carried out with care, however, to avoid problems with growing populations of rats, which are themselves introduced predators (Courchamp et al., 2003). All of Fiji's cave dwelling species are threatened and it would therefore be valuable to enlist the cooperation of landowners to minimize, or preferably halt, the harvesting of bats in caves, and to minimize harvesting of $P$. samoensis on small islands. For tourist visits to caves with nursing colonies of $N$. macdonaldi a code of conduct that minimizes disturbance is required; this needs to be negotiated between landowners and tour operators.

The metapopulation dynamics (Hanski \& Gilpin, 1991) of E. semicaudata and P. samoensis, whereby extirpation of a species on an island by a stochastic event such as a hurricane is followed by recolonization from another population, probably allows these species to persist on groups of small islands. However, anthropogenic effects are increasing the island extinction rate whilst at the same time reducing the potential sources of colonizers and this may result in progressive reduction in the range of these species. This could be countered with reintroduction programmes.

Based on our survey and conclusions we recommend that the following require further study: (1) Survey work to identify small and medium islands with viable populations of E. semicaudata and to locate any other roosts of this species and of N. macdonaldi and C. bregullae. (2) Clarification of the potential occurrence of $M$. acrodonta on Vanua Levu, and of whether the species is restricted on Taveuni to montane forest or also uses lowland forest; because of the extreme rarity and small range of this species a captive breeding programme is warranted, and this would have the advantage of raising the profile of this species within Fiji. (3) The role of bats as seed dispersers and pollinators as this may be critical to the long-term future of Fiji's forests. (4) Inter-island movements by E. semicaudata and P. samoensis, to understand the dynamics of both species and identify conservation units, possibly including studies of genetic differentiation among islands and island groups. (5) The dynamics of the remnants of native forest on small and medium sized islands, to aid the management of both the forest and its bat species. (6) The potential role of pathogens in the decline of E. semicaudata.

Legislation protecting bats, taking into account their occasional, traditional consumption, would be an important conservation tool if associated with a campaign to publicize the uniqueness of the Fijian bat fauna and their keystone ecological role. As most of the land in Fiji is still traditionally owned and landowners are sensitive to its preservation, we believe they will be receptive to proposals for bat conservation.

\section{Acknowledgements}

We are very grateful to the Mataqali and their chiefs who kindly granted us permission to survey the bats on their land. We are also grateful to the many people who, throughout Fiji, received us warmly in their homes, guided us to sites, and shared their knowledge. Dick Watling gave us indispensable advice during the preparation and implementation of the project. Peter Harlow allowed us to accompany him on the crested iguana survey that he coordinated, sponsored by the BP Conservation Programme, giving us an opportunity to survey the Yasawa islands. The project was funded by a grant from the $100 \%$ Fund of Fauna \& Flora International and by the parent institutions of the participants. The project was carried 
out whilst JMP was on sabbatical leave at the University of the South Pacific, Suva, Fiji, and he thanks the University for their support during his stay.

\section{References}

Atkinson, I.A.E. \& Atkinson, T.J. (2000) Land vertebrates as invasive species on the islands of the South Pacific Regional Environment Programme. In Invasive Species in the Pacific: A Technical Review and Draft Regional Strategy (ed. G. Sherley), pp. 19-84. SPREP, Apia, Samoa.

Banack, S.A. (1998) Diet selection and habitat use by flying foxes (Genus Pteropus). Ecology, 76, 149-1967.

Brooke, A.P. (2001) Population status and behaviours of the Samoan flying fox (Pteropus samoensis) on Tutuila Island, American Samoa. Journal of Zoology, 254, 309-319.

Brooke, A.P. \& Tschapka, M. (2002) Threats from over-hunting to the flying fox, Pteropus tonganus, (Chiroptera: Pteropodidae) on Niue Island, South Pacific Ocean. Biological Conservation, 103, 343-348.

Clunie, F. (1985) Notes on the bats and birds of Rotuma. Domodomo, 3, 153-160.

Courchamp, F., Chapuis, J.-L. \& Pascal, M. (2003) Mammal invaders on islands: impact, control and control impact. Biological Reviews, 78, 347-383.

Cox, P.A., Elmqvist, T., Pierson, E. \& Rainey, W.E. (1991) Flying foxes as strong interactors in South Pacific island ecosystems: a conservation hypothesis. Conservation Biology, 5, 448-454.

Craig, P., Trail, P. \& Morrell, T.E. (1994) The decline of fruit bats in American Samoa due to hurricanes and over-hunting. Biological Conservation, 69, 261-266.

Elmqvist, T., Cox, P.A., Rainey, W.E. \& Pierson, E.D. (1992) Restricted pollination on oceanic islands: pollination of Ceiba pentandra by flying foxes in Samoa. Biotropica, 24, 15-23.

Esselstyn, J.A., Wiles, G.J. \& Amar, A. (2004) Habitat use of the Pacific sheath-tailed bat (Emballonura semicaudata) on Aguiguan, Mariana Islands. Acta Chiropterologica, 6, 303-308.

Fisher, D. \& Tasker, E. (1997) Natural history of the New Georgia monkey-faced bat Pteralopex sp. nov. from the Solomon Islands. Pacific Conservation Biology, 3, 134-142.

Flannery, T.F. (1989) Flying foxes in Melanesia: populations at risk. Bats, 4, 5-7.

Flannery, T.F. (1995) Mammals of the South-West Pacific \& Moluccan Islands. Australian Museum/Reed Books, Chatswood, Australia.

Fleming, T.H. \& Eby, P. (2003) Ecology of bat migration. In Bat Ecology (eds T.H. Kunz \& M.B. Fenton), pp. 156-208. University of Chicago Press, Chicago, USA.

Gibbons, J.R.H. (1984) Iguanas of the South Pacific. Oryx, 18, 82-91.

Gilbert, T. (1984) Limestone and volcanic caves of the Fiji Islands. Transactions of the British Cave Research Association, 11, 105-118.

Grant, G.S., Banack, S.A. \& Trail, P. (1994) Decline of the sheath-tailed bat Emballonura semicaudata (Chiroptera: Emballonuridae) on American Samoa. Micronesica, 27, 133-137.

Hanski, I. \& Gilpin, M. (1991) Metapopulation dynamics: brief history and conceptual domain. Biological Journal of the Linnean Society, 42, 3-16.

Harlow, P.S., Fisher, M., Tuiwawa, M., Biciloa, P.N., Palmeirim, J.M., Mersai, C., Naidu, S., Naikatini, A., Thaman, B., Niukula, J. \& Strand, E. (2007) The decline of the endemic Fijian crested iguana Brachylophus vitiensis in the Yasawa and Mamanuca archipelagos, western Fiji. Oryx, 41, 44-50.
Heaney, L.R. \& Heideman, P.D. (1987) Philippine fruit bats: endangered and extinct. Bats, 5, 3-5.

Helgen, K.M. (2005) Systematics of the Pacific monkey-faced bats (Chiroptera: Pteropodidae) with a new species of Pteralopex and a new Fijian genus. Systematics and Biodiversity, 3, 433-453.

Hill, J.E. \& Beckon, W.N. (1978) A new species of Pteralopex Thomas, 1888 (Chiroptera: Pteropodidae) from the Fiji Islands. Bulletin of the British Museum (Natural History), Zoology 34, 65-82.

Hutson, A.M., Mickleburgh, S.P. \& Racey, P.A. (compilers) (2001) Microchiropteran Bats: Global Status Survey and Conservation Plan. IUCN/Species Survival Commission Chiroptera Specialist Group. IUCN, Gland, Switzerland and Cambridge, UK.

Ingleby, S. \& Flannery, T. (1991) A Survey of the Mammals of Fiji: Report to the Government of Fiji. Unpublished Report.

Australian Museum in collaboration with the National Trust of Fiji and the Ministry of Primary Industries, Fiji.

IUCN (2001) 2001 Categories and Criteria (version 3.1). IUCN, Gland, Switzerland [http://www.iucnredlist.org/info/ categories_criteria2001, accessed 28 September 2007].

IUCN (2003) Guidelines for Application of IUCN Red List Criteria at Regional Levels: Version 3.0. IUCN, Gland, Switzerland and Cambridge, UK. [http://www.iucn.org/themes/ssc/ redlists/regionalguidelines.htm, accessed 28 September 2007].

IUCN (2006) Guidelines for Using the IUCN Red List Categories and Criteria. Version 6.2 (December 2006). IUCN, Gland, Switzerland and Cambridge, UK. [http://intranet.iucn.org/ webfiles/doc/SSC/RedList/RedListGuidelines.pdf, accessed 28 September 2007].

IUCN (2007) 2007 IUCN Red List of Threatened Species. IUCN, Gland, Switzerland \& Cambridge, UK [http:// www.iucnredlist.orgaccessed 28 September 2007].

Koopman, K.F. (1997) The subspecies of Emballonura semicaudata (Chiroptera: Emballonuridae). Journal of Mammalogy, 78, 358-360.

Koopman, K.F. \& Steadman, D.W. (1995) Extinction and biogeography of bats on Eua, Kingdom of Tonga. American Museum Novitates, 3125, 1-13.

Lemke, T.O. (1986) Distribution and status of the sheath-tailed bat (Emballonura semicaudata) in the Mariana Islands. Journal of Mammalogy, 67, 743-746.

Long, K. \& Robley, A. (2004) Cost Effective Feral Animal Exclusion Fencing for Areas of High Conservation Value in Australia. Department of Sustainability and the Environment, Melbourne, Australia.

Marques, J.T., Rainho, A., Carapuço, M., Oliveira, P. \& Palmeirim, J.M. (2004) Foraging behaviour and habitat use by the European free-tailed bat Tadarida teniotis. Acta Chiropterologica, 6, 99-110.

McConkey, K.R. \& Drake, D.R. (2002) Extinct pigeons and declining bat populations: are large seeds still being dispersed in the tropical Pacific? In Frugivory and Seed Dispersal: Evolutionary and Conservation Perspectives (eds D. Levey W. Silva, \& M. Galetti) pp. 381-395. CAB International, Wallingford, UK.

McConkey, K.R., Drake, D.R., Franklin, J. \& Tonga, F. (2004) Effects of Cyclone Waka on flying foxes (Pteropus tonganus) in the Vava'u Islands of Tonga. Journal of Tropical Ecology, 20, 555-561.

McNab, B.K. (2002) Minimizing energy expenditure facilitates vertebrate persistence on oceanic islands. Ecology Letters, 5, 693-704. 
Medway, Lord \& Marshall, A.G. (1975) Terrestrial vertebrates of the New Hebrides: origin and distribution. Philosophical Transactions of the Royal Society B, 272, 432-465.

Mickleburgh, S.P., Hutson, A.M. \& Racey, P.A. (1992) Old World Fruit Bats - An Action Plan for Their Conservation. IUCN, Gland, Switzerland.

Mickleburgh, S.P., Hutson, A.M. \& Racey, P.A. (2002) A review of the global status of bats. Oryx, 36, 18-34.

Miller, C.A. \& Wilson, D.E. (1997) Pteropus tonganus. Mammalian Species no. 552, 1-6.

Morley, C.G. (2004) Has the invasive mongoose Herpestes javanicus yet reached the island of Taveuni, Fiji? Oryx, 38, 457-460.

Nelson, J.E. \& Hamilton-Smith, E. (1982) Some observations on Notopteris macdonaldi (Chiroptera: Pteropodidae). Australian Mammalogy, 5, 247-252.

Nunn, P.D. (1997) Late Quaternary environmental changes on Pacific islands: controversy, certainty and conjecture. Journal of Quaternary Science, 12, 443-450.

Parnaby, H.E. (2002a). A new species of long-eared bat (Nyctophilus: Vespertilionidae) from New Caledonia. Australian Mammalogy, 23, 115-124.

Parnaby, H.E. (2002b) A taxonomic review of the genus Pteralopex (Chiroptera: Pteropodidae), the monkey-faced bats of the south-western Pacific. Australian Mammalogy, 23, 145-162.

Pernetta, J.C. \& Watling, D. (1978) The introduced and native terrestrial vertebrates of Fiji. Pacific Science, 32, 223-244.

Pierson, E.D., Elmqvist, T., Rainey, W.E. \& Cox, P.A. (1996) Effects of tropical cyclonic storms on flying fox populations on the South Pacific islands of Samoa. Conservation Biology, 10, 438-451.

Racey, P.A. \& Entwistle, A.C. (2003) Conservation ecology of bats. In Bat Ecology (eds T.H. Kunz \& M.B. Fenton), pp. 680743. University of Chicago Press, Chicago, USA.

Rainey, W.E. (1998) Conservation of bats on remote Indo-Pacific islands. In Bat Biology and Conservation (eds T.H. Kunz \& P.A. Racey), pp. 326-341. Smithsonian Institution Press, Washington, DC, USA.

Rainey, W.E., Pierson, E.D., Elmqvist, T. \& Cox, P.A. (1995) The role of flying foxes (Pteropodidae) in oceanic island ecosystems of the Pacific. In Ecology, Evolution and Behaviour of Bats (eds P.A. Racey \& S.M. Swift), pp. 47-62. Oxford University Press, Oxford UK.

Ransome, R. (1990) The Natural History of Hibernating Bats. Christopher Helm, London, UK.

Sanborn, C.C. \& Nicholson, A.J. (1950) Bats from New Caledonia, the Solomon Islands, and New Hebrides. Fieldiana Zoology, 31, 313-338.

Sawyer, B. \& Andrews, E.C. (1901) Notes on the caves of Fiji, with special reference to Lau. Proceedings of the Linnean Society of New South Wales, 26, 91-106.
Steadman, D.W. \& Martin, P.S. (2003) The Late Quaternary extinction and future resurrection of birds on Pacific islands. Earth-Science Reviews, 61, 133-147.

Tarburton, M.K. (2002) Demise of the Polynesian sheath-tailed bat Emballonura semicaudata in Samoa. Micronesica, 34, 105108

Tuttle, M. (1977) Gating as a means of protecting cave dwelling bats. In National Cave Bat Management Symposium Proceedings (eds T. Aley \& D. Rhodes), pp. 77-82. Speleobooks, Albuquerque, USA.

Utzurrum, R.C.B., Wiles, G.J., Brooke, A.P. \& Worthington, D.J. (2003) Count Methods and Population Trends in Pacific Island Flying Foxes. In Monitoring Trends in Bat Populations of the United States and Territories: Problems and Prospects (eds T.J. O'Shea \& M.A. Bogan), pp. 49-62. Information and Technology Report, USGS/BRD/ITR, USGS, USA.

Watling, D. \& Pernetta, J.C. (1978) Limestone caves in the Sigatoka Valley, Viti Levu, Fiji. Studies in Speleology, 3, 78-86.

Wiles, G.J. (1997) Abundance, biology, and human exploitation of bats in the Palau Islands. Journal of Zoology, 241, 203-227.

Wilson, D.E. \& Engbring, J. (1992) The flying foxes Pteropus samoensis and Pteropus tonganus: status in Fiji and Samoa. In Pacific Island Flying Foxes: Proceedings of An International Conservation Conference (eds D.E. Wilson \& G.L. Graham), pp. 74-101. Biological Report 90(23), USFWS, Washington, DC, USA.

Worthy, T.H. \& Anderson, A. (1999) Research on the Caves of Viti Levu, Fiji, June 1997-October 1998, and their Significance for Palaeontology and Archaeology. Unpublished Report.

\section{Appendix}

The appendix for this article is available online at http:/ /journals.cambridge.org

\section{Biographical sketches}

Jorge Palmeirim has a wide interest in the ecology and conservation of birds and bats, which he has studied in Europe, Africa and the Americas. The other members of the team have a range of interests in the ecology and natural history of Fiji, including bats, herpetofauna and plants. All the team were resident in Fiji at the time of this survey, and pooled their various expertise, including knowledge of the various island groups, for this first extensive survey of the bats of the Fiji islands. Marika Tuiwawa is a trustee of the recently formed NGO NatureFiji-MareqetiViti (http:// www.naturefiji.org/), which works for the conservation and sustainable management of Fiji's fauna, flora and landscapes. 